\title{
LOCHINVAR RANCH, NORTHERN RHODESIA
}

Readers of Oryx, and members of the society who came to the Annual General Meeting in April, will realize the importance for the preservation of the red lechwe, of Lochinvar Ranch on the Kafue flats, Northern Rhodesia.

Our honorary treasurer, Mr. Ian Malcolmson, has paid a special visit to the ranch and has given the following report:-

"The owners of the Lochinvar Ranch very kindly made arrangements for me to pay a short visit to the ranch in March this year. The area of this privately-owned ranch is 110,000 acres. The homestead is situated in a wonderful position on the edge of some low hills and from the verandah of the house you look away across the plain towards the Kafue river, which is along the northern boundary.

On the evening of my arrival, I walked on to the verandah and saw a number of eland which were still grazing in the open a few hundred yards from the house. I then took a run round the fairly thick bush country on the edge of the hills in the hope of catching a glimpse of kudu or possibly impala, but I was unlucky as these creatures, particularly the kudu, are very shy.

Early the next morning, I took a walk to some hot springs, which are a short distance from the house, and which would make an admirable swimming pool for those who like to bathe in clear running warm water. We then went off to spend the day near a large swamp on the ranch, which is created during the rainy season by the flood water of the Kafue river. After we had gone a mile or so, we came to the fence dividing the ranch proper from the rest of the area which is now a game reserve and we passed a notice giving a warning that there was to be no shooting. Although the grass was very long and it was the worst time of the year to see game we soon noticed one or two lone wildebeest and a few zebra, but as we got nearer to the swamp, we saw great herds of these animals running into some hundreds. Lion were about, but were not seen as, being now the middle of the day they would be sleeping, hidden away in the shade of the undergrowth. Soon I saw my first red lechwe and then great herds of these beautiful red-coloured antelope numbering some thousands. They seemed quite peaceful and undisturbed by our presence, as it is only when the natives carry out their great periodical hunts that the lechwe get really disturbed and suffer tremendous losses. Perhaps the ranch is most famous for its red lechwe as it is estimated that something like 50 per cent of all lechwe on the Kafue flats make their home there. 
In the afternoon, we took a native canoe on the swamp to see the wonderful bird-life. At times the sky was full of endless varicties of birds including marabou storks, crested cranes, Egyptian geese, knobnose and other duck. During the course of our canoeing, my companion fell into the swamp within easy reach of a crocodile which had just submerged, but he climbed back none the worse except that he was soaked from head to foot; however the hot African sun dried him off within an hour. We returned to the homestead later that evening, hot and dusty, and refreshed ourselves on the verandah looking across those plains which are a paradise for game and truly an oasis of shelter for the wild life ; for the ranch is bounded on all sides by native reserves, and in these there are no animals left due to the endless trapping and shooting by natives. Long may Lochinvar remain as it now is."

We are indebted to the Game Preservation and IIunting Association of Northern Rhodesia for the following account of a visit to Lochinvar by Mr. James P. Chapin, Research Associate, American Museum of Natural History.

"In the Kafue Flats the people of Northern Rhodesia possess a naturalists' paradise, which it was my good fortune to visit recently in company with my wife. During the many years that I have been studying African birds in many scattered parts of the Continent, I have rarely seen such a variety of large birds in the. great numbers as we observed near Lochinvar Ranch.

Last June Mrs. Chapin and I were invited to attend a meeting of the Socicty for the Preservation of the Fauna of Northern Rhodesia. The meeting was held at Chikupi Farm, the home of Mr. and Mrs. Lafone, and there we admired a series of films showing the big game of Northern Rhodesia. Knowing of our interest in birds, Mr. B. L. Mitchell and Major Ian Grimwood assured us that we would find on the Kafue flats great concentrations of aquatic birds, along with vast herds of lechwe. We are accustomed to the enthusiasm of local naturalists for their favoured areas, but were totally unprepared for the spectacle that greeted us, when some weeks later we accepted an invitation to Lochinvar farm on the southern edge of the Kafue Flats. There we met Mr. and Mrs. Johannes van Zyl, who manage the ranch and are enthusiastic guardians of the animals and birds that are found there in such great numbers.

During the drive from the ranch to the Flats we were tempted to linger and gloat over the graceful crowned cranes, the stately saddle-bill stork, the secretary-bird, a superb tawny cagle at its 
nest, the scattering of lechwe, zebra and wildebeest. These, we were told, were just a sampling of what was ahead. This proved to be true. As we reached the flats we were astounded at the number of birds. On the edge of the marsh were huge flocks of spur-winged geese in the grass. Farther out, white-faced tree ducks numbering several thousand, arose like a cloud of smoke blackening the sky and then settled again in the marsh. A squadron of roseate pelicans soared over in perfect formation. A dozen or more wattled cranes permitted an approach close enough for a photograph, before they spread their tremendous wings and took off over the flats.

Everywhere we looked there were birds-cormorants, snakebirds, goliath and grey herons, marabous, egrets, sacred ibis, open-bill storks, gulls and terns. Magnificent fishing eagles turned and wheeled in the sky above us, drawing our attention by their loud but pleasing cries. The graceful bateleur eagle floated overhead on motionless wings. There were bustards, lapwings and shore-birds of several kinds, some of them visitors from Europe. The smaller land birds were present, too : larks, pipits, wagtails and wheatears flew up ahead of the car. Almost every bush or tree harboured a cape turtle dove or a namaqua dove, or even a glittering sunbird. At Chunga the familiar little ruddy waxbill and the blue waxbill flitted about, and grayrumped swallows were looking for nesting sites. On some dry, bare carth not far from the edge of the marsh we found numbers of pratincoles skimming low over the ground. They are ploverlike birds that fly like swallows and catch insects on the wing. One was so loath to fly as our car approached that we investigated more closely and to our delight found its nest with two heavily blotched eggs. Later another nest was located in much the same fashion.

With Mr. van Zyl we went down the creek in a motor-boat to the main stream of the Kafuc. This excursion provided marvellous, intimate views of many of the birds we had watched from a distance on the flats and added more species to our evergrowing list; lily-trotters, pied and malachite kingfishers, pygmy gcese, lapwings, ducks, etc. It would be superflous to give here a list of all the attractive birds that we were shown on the Kafue Flats. I doubt that I have ever beheld anywhere else such an impressive assembly.

Although we were most interested in the birds, we could not help but marvel at the enormous herds of lechwe on the flat lands of the marsh and stretching away to the horizon. It was impossible to estimate the numbers, which most certainly 
reached well into the thousands. With the lechwe were many zebra and wildebeest. In areas of short grass we watched the graceful, little oribi in twos and threes. We were deeply impressed by the fact that cattle were being grazed in close proximity to vast herds of wild animals. This seemed to us all the more remarkable because so often the introduction of cattle has meant the destruction and disappearance of the wild game. The Lochinvar Estates, who manage this area so wisely, are to be commended for preserving this happy state of affairs. We hope that in other areas about the Kafue Flats similar policies are being followed. Indeed, to safeguard the future of this remarkable fauna, it would certainly be advisable for Northern Rhodesian authorities to set up a game reserve in this region, where those who appreciate wild nature could come and enjoy the same glorious sights that we experienced. 